\title{
Risk Scores and Acute Coronary Syndrome
}

\author{
Eduardo Maffini da Rosa, William Cenci Tormen, William Schalins May \\ Universidade de Caxias do Sul - Liga Acadêmica de Estudos e Ações em Cardiologia, Caxias do Sul, RS - Brazil
}

\section{Dear Editor,}

Our study group on coronary diseases would like to congratulate the authors for the original article publication in this journal (Arq. Bras. Cardiol. 2009; 93(4): 343-351)1',

\section{Keywords}

Acute coronary syndrome/therapy; diagnostic; prognosis. presenting a risk score for acute coronary syndrome without ST segment supra-unlevelling

First of all, despite the existence of other risk stratification models, we believe that the new scores are necessary, because they reflect not only the natural history of the disease, but the interaction between this and the moment diagnostic, therapeutic and prognostic capacity. Thus, the risk scores that were good in the past may not be so precise in the future ${ }^{2-4}$.

Finally, as we find it a relevant issue, we would like to know the therapeutic strategies used in such study patients.

Mailing address: William Cenci Tormen

Rua Ernesto Marsiaj, 7944/211B - Petrópolis - 95070-530 - Caxias do Sul, RS - Brazil

E-mail: wctormen@ucs.br

Manuscript received December 03, 2009; revised manuscript received December 03, 2009; accepted March 15, 2010.

\section{References}

1. Santos ES, Timerman A, Baltar VT, Castillo MTC, Pereira MP, Minuzzo L, et al. Escore de risco Dante Pazzanese para síndrome coronariana aguda sem supradesnivelamento do segmento ST. Arq Bras Cardiol. 2009; 93 (4): 343-51.

2. Laurenti R, Buchalla CM, Caratin V deS. Ischemic heart disease: hospitalization, length of stay and expenses in Brazil from 1993 to 1997. Arq Bras Cardiol. 2000; 74 (6): 483-92.

3. Anderson JL, Adams CD, Antman EM, Bridges CR, Califf RM, Casey DE, Jr., et al. ACC/AHA 2007 guidelines for the management of patients with unstable angina/non ST-elevation myocardial infarction: a report of the American College of Cardiology/American Heart Association Task Force on Practice Guidelines
(Writing Committee to Revise the 2002 Guidelines for the Management of Patients With Unstable Angina/Non ST-Elevation Myocardial Infarction): developed in collaboration with the American College of Emergency Physicians, the Society for Cardiovascular Angiography and Interventions, and the Society of Thoracic Surgeons: endorsed by the American Association of Cardiovascular and Pulmonary Rehabilitation and the Society for Academic Emergency Medicine. Circulation. 2007; 116 (7): e148-304.

4. Boersma E, Pieper KS, Steyerberg EW, Wilcox RG, Chang WC, Lee KL, et al. Predictors of outcome in patients with acute coronary syndromes without persistent ST-segment elevation: results from an international trial of 9461 patients. The PURSUIT Investigators. Circulation. 2000; 101 (22): 2557-67.

\section{Reply to the editor}

\section{Dear Editor,}

The First Aid Clinic of Instituto Dante Pazzanese de Cardiologia corresponds to an emergency section open to care and hospitalization in the most different clinical situations, where patients with acute coronary syndrome (ACS) correspond to almost $40.0 \%$ of these hospitalizations ${ }^{1}$. The patient's medical conduct with ACS without ST supra (unstable angina or acute infarctation of the myocardium) is based on the recommendations of the national and international guidelines ${ }^{2,3}$.

The population of patients of risk score development Dante Pazzanese ${ }^{4}$ receives intensive medication with betablockers (93,0\%), acetylsalicylic acid (97.5\%), endovenous nitroglycerin (94.3\%), antithrombinics (84.3\%), thienopyridinics (89.5\%), angiotensin converter enzyme inhibitor (84.1\%) and statins (94.4\%). All medications were started in the hospitalization.

The indication of cinecoronariography was based on the presence of independent variables for the adverse event risks, such as: clinical history data, acute ischemic changes of the electrocardiogram or increase of the myocardic necrosis markers. The cinecoronariography was requested in the first 48 hours after the hospitalization and was performed in 734 patients (71.5\%). 
The myocardic revascularization (MR) procedure, percutaneous coronary intervention $(\mathrm{PCl})$ or surgery, was indicated in 417 patients (40.6\%) of the global population [PCI 276 patients (26.9\%); MR surgery 141 patients (13.7\%)].
Analyzing only the patients who underwent the cinecoronariography, the MR procedure indication occurred in 373 patients (50.8\%), where the $\mathrm{PCl}$ indication occurred in 259 (35.3\%) and surgery in 114 (15.5\%).

\section{References}

1. Santos ES, Minuzzo L, Pereira MP, Castillo MTC, Palacio MA, Ramos RF, et al. Registro de síndrome coronariana aguda em um centro de emergências em cardiologia. Arq Bras Cardiol. 2006; 87 (5): 597-602.

2. Sociedade Brasileira de Cardiologia. Diretrizes sobre Angina instável e infarto agudo do miocárdio sem supradesnível do segmento ST: Parte II: condutas nos pacientes de risco intermediário e alto. Arq Bras Cardiol. 2001; 77 (supl 2): 23-37.

3. Anderson JL, Adams CD, Antman EM, Bridges CR, Califf RM, Casey DE Jr, et

al. ACC/AHA 2007 Guidelines for the management of patients with unstable angina/non ST-elevation myocardial infarction: a report of the American College of Cardiology/American Heart Association Task Force on Practice Guidelines. Circulation. 2007; 116 (7): e148 - 304.

4. Santos ES, Timerman A, Baltar VT, Castillo MTC, Pereira MP, Minuzzo L, et al. Escore de risco Dante Pazzanese para Síndrome Coronariana Aguda sem Supradesnivelamento do Segmento ST. Arq Bras Cardiol. 2009; 93 (4): 343-51. 